\title{
Effects of toxic Alexandrium tamarense on behavior, hemocyte responses and development of brown ring disease in Manila clams
}

\author{
V. M. Bricelj ${ }^{1, *}$, Susan E. Ford ${ }^{2}$, Christophe Lambert ${ }^{3}$, Annaick Barbou ${ }^{3}$, \\ Christine Paillard ${ }^{3}$ \\ ${ }^{1}$ Institute of Marine and Coastal Sciences, Rutgers University, New Brunswick, New Jersey 08901, USA \\ ${ }^{2}$ Haskin Shellfish Research Laboratory, Rutgers University, Port Norris, New Jersey 08349, USA \\ ${ }^{3}$ Institut Universitaire Européen de la Mer, LEMAR, Technopôle Brest Iroise, 29280 Plouzané, France
}

\begin{abstract}
In this study of short-term exposure of Ruditapes philippinarum from Brittany, France, to an Alexandrium tamarense isolate that produces high concentrations of paralytic shellfish toxins (PSTs), the effects of the isolate on clam fitness, toxin uptake, and the response of hemocytes (responsible for internal defense in bivalves) were examined. Adults exhibited individual variability in resistance to the effects of PSTs, measured by their burrowing capacity. If genetically based, this may (1) indicate that resistance is under natural selection and (2) provide a new model to advance our understanding of the molecular basis for PST resistance in bivalves, so far determined only in Mya arenaria. Juvenile clams were more vulnerable to PSTs than adults, experiencing $100 \%$ burrowing incapacitation within $1 \mathrm{~d}$ of exposure to $A$. tamarense. They also experienced growth suppression and high mortalities following $4 \mathrm{~d}$ of toxification. Juveniles challenged with Vibrio tapetis, the cause of brown ring disease (BRD), and exposed to $A$. tamarense, developed significantly fewer BRD symptoms relative to controls fed non-toxic algae, but suffered higher mortality. Adult clams exposed to $A$. tamarense showed a significant increase in hemocyte concentrations and a small, but significant, decrease in phagocytic activity, and no effect on hemocyte viability or other functional parameters. We speculate that the inhibitory effects on BRD progression may be attributable to toxicity of PSTs to $V$. tapetis, inability of juveniles to activate the shell conchiolin-deposition response, and/or an overall increase in phagocytic cells induced by $A$. tamarense. Harmful algae and pathogens may thus interact and modulate the effects of disease in bivalve populations.
\end{abstract}

KEY WORDS: Ruditapes philippinarum · Paralytic shellfish toxins · Vibrio $\cdot$ Burrowing $\cdot$ Hemocytes Resale or republication not permitted without written consent of the publisher

\section{INTRODUCTION}

The Japanese littleneck or Manila clam Venerupis (= Ruditapes $=$ Tapes $)$ philippinarum (Adams \& Reeves, 1850), a native of the western Pacific, is a major commercial species worldwide, especially in Canada, the USA, France, the north Adriatic lagoons in Italy, Great Britain, Japan, China, and South Korea (Goulletquer 1997). It was deliberately introduced to France from the Pacific coast of North America (Puget Sound) in the early 1970s, and in France, naturalized populations are found on both Atlantic and Mediterranean coasts, especially in the Gulf of Morbihan (southern Brittany) and Arcachon Bay (SW France) (Flassch \& Leborgne 1992, Dang et al. 2008). Manila clams occur in eutrophic, sheltered environments, in a wide range of sediments, where they burrow only to shallow depths $(\leq 10 \mathrm{~cm})$ and attain a maximum shell length (SL) of $\sim 65$ mm (Paillard et al. 2008).

The Atlantic coast of France has been affected since the late 1980s by blooms of the paralytic shellfish toxin (PST) producer Alexandrium minutum, especially along the NW coast of Brittany (Réseau National de Surveillance du Phytoplancton et des Phycotoxines 
[REPHY]; www.ifremer.fr/envlit/surveillance/rephy.htm). Since the late 1990s, A. catenella has occurred in the Thau Lagoon on the Mediterranean coast (Lilly et al. 2002) and has expanded along the NW Mediterranean coast (Vila et al. 2001). Prior studies on laboratory exposure of Manila clams to PST-producing Alexandrium spp. have been limited to the use of very low-toxicity strains, including an A. tamarense isolate from the South China Sea characterized by the predominance of low-potency $\mathrm{N}$-sulfocarbamoyl toxins (toxicity $=3.2 \mathrm{pg}$ saxitoxin equivalents [STXeq] cell ${ }^{-1}$ ) (Li \& Wang 2001, Li et al. 2002), an A. minutum isolate from Morlaix Bay, Brittany (2.4 pg STXeq cell ${ }^{-1}$ ) (Bougrier et al. 2001) that produces almost exclusively gonyautoxins (GTXs) (Lassus et al. 1994), and an A. catenella isolate from the Thau Lagoon (5 to 15 pg STXeq cell ${ }^{-1}$ ) (Hégaret et al. 2007a).

Manila clams can accumulate relatively high levels of PSTs in the natural environment, attaining maximum toxicities of 2000 to $6100 \mu \mathrm{g}$ STXeq $100 \mathrm{~g}^{-1}$ wet weight of whole tissues (reviewed by Bricelj \& Shumway 1998). These levels are an order of magnitude lower than those accumulated by mussels Mytilus edulis and scallops Pecten maximum, but much higher than those of oysters Crassostrea gigas (Lassus et al. 1989) and more comparable to those attained by the softshell clam Mya arenaria (Bricelj \& Shumway 1998).

Paralytic shellfish toxins act by blocking voltagegated sodium $\left(\mathrm{Na}^{+}\right)$channels in excitable nerve and muscle cells (Catterall 2000). Exposure to toxic Alexandrium spp. thus causes paralysis of the foot and pallial musculature in sensitive Mya arenaria, leading to burrowing incapacitation (MacQuarrie \& Bricelj 2008, Bricelj et al. 2010), which may increase predatory risk in nature. In this bivalve species, pronounced individual differences in the capacity to accumulate PSTs and in the resistance to the effects of these neurotoxins have been attributed to a single point mutation that encodes for a single amino acid substitution in Domain II of the pore region of the $\mathrm{Na}^{+}$channel protein (Bricelj et al. 2005). Clams with a history of exposure to PSTs have a higher proportion of resistant individuals compared to unexposed populations, based on the effect of PSTs on burrowing behavior, in vitro nerve resistance to STX, and genotype, indicating that PSTs can select for resistance in natural populations (Bricelj et al. 2004, Connell et al. 2007). We hypothesize that individual variation in resistance to PSTs may also occur in Ruditapes philippinarum, a species that, like $M$. arenaria, is widely distributed in coastal waters with varying exposure to PSTs, thus providing an alternate model species in which to investigate the molecular/genetic basis for resistance to PSTs among bivalve molluscs.

A number of previous studies have documented effects of bacterial pathogens and protozoan parasites (e.g. Oubella et al. 1993, Goedken et al. 2005, Allam \&
Ford 2006), and harmful algal blooms (HABs) (e.g. Hégaret \& Wikfors 2005) on hemocyte parameters and other defense-related factors in bivalves. Blooms of toxic microalgae can, however, co-occur with bivalve bacterial and protistan pathogens, yet few studies have examined their interactive effects on bivalve populations (Hégaret et al. 2007a, da Silva et al. 2008). In Europe, the Manila clam is affected by brown ring disease (BRD) caused by the bacterium Vibrio tapetis, which results in characteristic brown conchiolin deposits on the inner surface of the shells and which can lead to heavy mortalities of juveniles and adults, especially in cultured populations (Paillard \& Maes 1990, Paillard et al. 2004). In NW France, blooms of Alexandrium minutum typically occur in the summer. Heavy clam mortalities associated with BRD generally occur in the winter and spring, resulting from the development of disease during the summer and fall. Thus, interactive effects between PSTs and the progression of BRD could occur in nature.

The main objectives of this study were thus to determine under controlled laboratory conditions (1) the potential interactive effect on the development of BRD of exposing juvenile Ruditapes philippinarum to toxic Alexandrium spp. cells after challenge by Vibrio tapetis, (2) the susceptibility of juvenile and adult Manila clams to exposure to toxigenic A. tamarense as measured by the effects on burrowing behavior, and (3) the effect of exposure to Alexandrium spp. on the concentrations and functions of hemocytes extracted from hemolymph of adults, given that hemocytes play a key role in both cellular and humoral defense in bivalve molluscs (Cheng 1996). An important additional objective of this study was to assess the individual variability in susceptibility to PSTs in an adult Manila clam population from the coast of Brittany, France, which is known to experience blooms of Alexandrium spp. of relatively low toxicity compared to those prevalent in the NW Pacific coast of North America. Finally, these laboratory experiments allowed determination of the short-term capacity for accumulation and biotransformation of individual PSTs in tissues of Manila clams following exposure to a highly toxic A. tamarense isolate. Biotransformation of low-potency toxins in dinoflagellate cells to more potent PSTs in bivalve tissues is important to determine, as it can potentially lead to increased shellfish toxicity.

\section{MATERIALS AND METHODS}

All experiments were conducted at the Laboratoire des Sciences de L'Environnement Marin (LEMAR), Institut Universitaire Européen de la Mer (IUEM), Brittany, France. 
Microalgal and bacterial cultures. Non-axenic stock cultures of Alexandrium tamarense (strain PR18b) isolated from the estuary of the Gulf of St. Lawrence, Canada were air-shipped from the Institute for Marine Biosciences, National Research Council (IMB/NRC), Canada, to France. This strain was selected because there is already considerable information available on the in vivo responses of other bivalve species, including Mya arenaria, to this strain (e.g. Bricelj \& Shumway 1998, Bricelj et al. 2005, 2010), thus allowing interspecies comparisons. Its mean equivalent spherical diameter (ESD) as determined with a BeckmanCoulter Multisizer was $30.1 \mu \mathrm{m}$. Algae were batch cultured non-axenically at $14^{\circ} \mathrm{C}$ and 35 salinity with a $14 \mathrm{~h}$ light:10 h dark cycle, in 21 glass flasks without aeration or in $10 \mathrm{l}$ round-bottom, aerated flasks, using an L1 medium modified by the addition of $\mathrm{NH}_{4} \mathrm{Cl}$ at a final concentration of $50 \mu \mathrm{M}$ (Guillard \& Hargraves 1993). Seawater for the smaller flasks was $0.22 \mu \mathrm{m}$ filtered and sterilized by microwaving using a protocol adapted from Keller et al. (1988). The nutrients were autoclaved separately before addition to the medium under a laminar hood and the final $\mathrm{pH}$ checked to ensure that it remained below 8. Non-toxic flagellates Pavlova spp. and Isochrysis galbana (strain T-iso) were mass cultured in f/2 medium (Guillard \& Ryther 1962) with aeration and under continuous light. All cultures were harvested in late exponential growth phase.

Vibrio tapetis (strain CECT4600) isolated from Ruditapes philippinarum in Landéda, northern Brittany, France (Paillard \& Maes 1990) was grown on ZoBell's 2216 agar -11 distilled water, $15 \mathrm{~g}$ agar (AES), $30 \mathrm{~g}$ sea salts (Sigma), $4 \mathrm{~g}$ peptone (AES), $1 \mathrm{~g}$ yeast extract (AES) and $0.1 \mathrm{~g}$ $\mathrm{FePO}_{4}$ (Merck) - at $18^{\circ} \mathrm{C}$ for $72 \mathrm{~h}$. Before in vivo inoculation experiments or in vitro hemocyte challenge, a $V$. tapetis suspension was prepared in sterile seawater (SSW) and the concentration adjusted to $5 \times 10^{8}$ bacteria $\mathrm{ml}^{-1}$, based on spectrophotometric determination of bacterial density at $490 \mathrm{~nm}$.

Expt 1: exposure of juvenile clams to toxic Alexandrium tamarense and Vibrio tapetis. Juvenile Manila clams were obtained from the Satmar, Marennes-Oléron nursery at an initial mean shell length (SL) of $12.5 \mathrm{~mm}( \pm 0.10 \mathrm{SE}$, range $=11.2$ to $13.8 \mathrm{~mm}, \mathrm{n}=50$ clams) on February 12, 2007. They were acclimated at LEMAR at $16^{\circ} \mathrm{C}$ and 35 salinity and kept on a maintenance diet of Pavlova spp. and/or Isochrysis galbana (strain T-iso), without sediment.

All juvenile clams were inoculated $2 \mathrm{~d}$ after their arrival (Day 0 of the experiment), one-half with 50 $\mu \mathrm{l}$ of Vibrio tapetis suspension in SSW $\left(2.5 \times 10^{7}\right.$ bacteria per individual) and the other half with the same volume of $0.22 \mu \mathrm{m}$ filtered seawater (FSW controls) following a protocol by Paillard \& Maes (1990) (Fig. 1). Prior to injection, the clams were kept out of water overnight and covered with wet paper towels to stimulate rapid opening upon re-immersion and thus to facilitate injection. A few minutes prior to inoculation they were placed in a shallow tray with seawater and algae. As soon as an individual opened its valves, the bacterial inoculum or FSW was injected into its pallial cavity with a 25 -gauge $5 / 8$ " needle attached to a $1 \mathrm{ml}$ tuberculin syringe. Clams were again kept out of water under moist towels until the following morning, when they were transferred to $6 \sim 151$ aerated static tanks, 3 with $V$. tapetis-inoculated clams and 3 with FSW controls, for a post-inoculation recovery period (Fig. 1). The tanks contained unfiltered, ambient seawater at salinity 35 and were held in a temperaturecontrolled room at $16^{\circ} \mathrm{C}$. Water in these tanks was changed daily, at which time dead clams were removed and recorded. Clams were batch-fed once a day by adding Pavlova spp. or Isochrysis galbana to achieve a total cell density of $\sim 60000$ cells ml ${ }^{-1}$ (maintenance diet). All water and materials used for $V$. tapetis-treated animals were chlorinated overnight prior to release. An initial sample of 30 clams was taken on Day 6 post-inoculation for baseline determination of dry tissue weight (DW) after oven-drying at $60^{\circ} \mathrm{C}$ for $24 \mathrm{~h}$.
Feb 12: Juvenile clams received from Satmar

Day 0: Inoculation with $V$. tapetis or $0.22 \mu \mathrm{m} \mathrm{FSW}$, in air with moist covering overnight

Day 1: Transfer to 6 static, aerated tanks, batch-fed maintenance diet; mortality monitored

Day 6: Clams collected for DW determination

Day 13: Start of toxification; 4 recirculating tanks, each with 3 trays ( 55 clams per tray) in sediment; continuous feeding

Day 14: Burrowing test; collection for PSP toxicity; toxification continues; mortality monitored

Day 16: End of toxification; collection for PSP toxicity; transfer to 12 static, aerated "recovery" tanks with sediment; batch-fed maintenance diet; mortality monitored

Day 28: End of experiment; clams processed for BRD staging and DW

Fig. 1. Ruditapes philippinarum. Chronology of experimental manipulations of juvenile Manila clams in Expt 1 
Clams experienced some mortalities in the days following inoculation, mainly in Vibrio tapetis-inoculated batches and primarily during the first $5 \mathrm{~d}$ post-inoculation (total losses were $<1.2 \%$ in controls and $<21 \%$ in $V$. tapetis-injected clams by Day 9 post-inoculation). Mortalities resulting from this initial handling/injection had ceased by Day 11 post-inoculation.

On Day 13 post-inoculation, clams were transferred to 4 aerated 451 tanks, each fitted with an externally mounted, low-pressure recirculating pump (Super King, Danner Mfg) that maintains algae in suspension but does not damage Alexandrium spp. cells. Two of these tanks received toxic Alexandrium tamarense maintained at a constant cell density of 50 cells $\mathrm{ml}^{-1}$ and 2 control tanks received Isochrysis galbana to maintain a volume equivalent cell concentration $\left(\sim 33000\right.$ cells $\left.\mathrm{ml}^{-1}\right)$ via continuous delivery from stock cultures with a Masterflex peristaltic pump. The resulting 4 treatments were as follows (Fig. 1): (1) FSW-injected and exposed to $A$. tamarense; (2) Vibrio tapetis-injected and exposed to A. tamarense; (3) V. tapetis-injected and fed I. galbana; and (4) FSW-injected and fed I. galbana. Treatment 4 was considered the control (no bacteria/no toxic algae).

Within each of the 4 tanks, clams were held in 3 separate trays ( $\mathrm{n}=55$ clams per tray) filled with a 6 to $7 \mathrm{~cm}$ deep layer of sediment (white quartz sand, Zolux®; $\sim 0.5 \mathrm{~mm}$ grain size) into which the clams were allowed to burrow prior to toxification (Fig. 1). The Alexandrium tamarense exposure concentration was selected based on prior experiments with juvenile (4 mm) Mya arenaria, in which 100 cells $\mathrm{ml}^{-1}$ caused severe mortalities, 10 cells $\mathrm{ml}^{-1}$ had no effect on survival or growth, although it affected motility, and 50 cells ml ${ }^{-1}$ caused $15 \%$ mortalities by the end of $2 \mathrm{wk}$ and severe growth inhibition (Bricelj et al. 2010). Cell densities of $A$. tamarense in the experimental tanks were determined microscopically and those of Isochrysis galbana were determined with an electronic Coulter counter.

Burrowing test. Burrowing capacity as a measure of susceptibility to PSTs was determined beginning on Day 14 after 24 h exposure to toxic cells (Fig. 1). Clams in all groups that had completely burrowed prior to toxification were removed from the sediment and placed on the surface in the same tanks, and the number of burrowed and non-burrowed clams was determined at the end of $2 \mathrm{~h}$. This period was based on preliminary trials showing that nearly all untreated clams would reburrow within $2 \mathrm{~h}$ after being removed from sediment. The criterion for considering a clam to be burrowed was that its umbo be under the sediment. Toxification was continued during and after the burrowing test for a total of $4 \mathrm{~d}$. At the end of the burrowing test, a subsample of clams (burrowed and nonburrowed) from toxified and control tanks was frozen at $-80^{\circ} \mathrm{C}$ for toxin analysis.
Progression of BRD. At the end of toxification (Day 16 post-inoculation), clams from the 4 treatments were divided, according to treatment, among 12 tanks (15 l) containing fresh seawater and sediment, and batchfed a maintenance diet of Isochrysis galbana, as previously, until the end of the experiment on Day 28 postinoculation (Fig. 1). The end point of the experiment was selected based on previous findings that the \% BRD prevalence in inoculated Manila clams reached $90 \%$ by Day 28 post-inoculation at $12^{\circ} \mathrm{C}$ (Paillard \& Maes 1990).

Daily observations were conducted to determine mortalities and the seawater in the tanks changed at the same time; dead clams were removed and preserved in $70 \%$ ethanol to assess BRD status. Clams were also sampled at the end of the experiment to determine the oven-dried DW of soft tissues ( $\mathrm{n}=30$ per treatment) and BRD status. Shells of the clams that died prior to the end of the study as well as those of survivors were observed under a dissecting microscope to determine the total BRD prevalence and the distribution of disease stages. The BRD symptoms were categorized on the 0 to 7 scoring system of Paillard \& Maes (1994), but combined into 4 conchiolin deposit groups (CDG0, CDGI [stages 1 to 2], CDGII [stage 3], CDGIII [stages 4 to 7]) (Paillard et al. 2004) for statistical analysis to avoid categories with $<5$ values. These groups reflect none, very light, intermediate, and moderate-heavy conchiolin deposits, respectively. The instantaneous daily growth coefficient $(k)$ was calculated from $k=\left[\left(\operatorname{lnDW}_{\mathrm{f}}-\operatorname{lnDW}_{\mathrm{o}}\right) / t\right] \times 100$, where $t=$ time interval in $\mathrm{d}$, and $\mathrm{DW}_{\mathrm{f}}$ and $\mathrm{DW}_{\mathrm{o}}$ are final and initial values determined on Day 28 and Day 6 post-inoculation, respectively.

Expt 2: exposure of adult clams to toxic Alexandrium tamarense. Adult clams were collected manually from an intertidal population at Tascon in the Gulf of Morbihan, Brittany, on January 4, 2007. Only burrowed clams were collected, as those lying at the sediment surface tend to have higher prevalence and severity of BRD than burrowed ones (Paillard \& Maes 1994). Experimental clams ranged in SL from 30.7 to $42.1 \mathrm{~mm}$, averaging $35.9 \mathrm{~mm}(\mathrm{SE}=0.23)$; mean DW of soft tissues $=307.1 \mathrm{mg}(\mathrm{SE}=71.8)$. They were initially held at LEMAR in flow-through Bay of Brest seawater at ambient temperature of 12 to $13^{\circ} \mathrm{C}$, and then transferred to the Institut Français de Recherche pour l'Exploitation de la Mer (IFREMER) hatchery at Argenton, where they were acclimated to the experimental temperature $\left(16^{\circ} \mathrm{C}\right)$ and fed an optimum ration of a mixed microalgal diet for $1 \mathrm{wk}$ prior to the start of the experiment.

Burrowing and toxin accumulation. Experimental clams were divided among 6 aerated aquaria (45 l) (16 to 20 individually numbered clams per aquarium), containing the same type of sediment as used for juvenile 
clams and using the same recirculating pumps. All clams burrowed before toxification. Three aquaria received Alexandrium tamarense harvested at $~ 8000$ cells $\mathrm{ml}^{-1}$ to attain an experimental concentration of 100 cells ml ${ }^{-1}$ and 3 received Isochrysis galbana stock cultures at a volume-equivalent concentration. A constant concentration was maintained via continuous delivery from stock cultures with a Masterflex peristaltic pump.

After $16 \mathrm{~h}$ of exposure to the toxic or non-toxic diet, all clams were removed from the sediment and laid horizontally on the substrate in their respective aquaria to determine the number of burrowed (umbo covered by sediment) and non-burrowed individuals at 30 min and then at hourly intervals over a total period of $12 \mathrm{~h}$.

Hemocyte responses. At the end of the burrowing test, hemolymph $(\sim 600 \mu \mathrm{l})$ was collected from the posterior adductor muscle of each treated and control clam using a 25 -gauge needle attached to a $1 \mathrm{ml}$ syringe. The sample was first examined microscopically to verify the presence of hemocytes and lack of debris, and stored temporarily in a $1.5 \mathrm{ml}$ microcentrifuge tube on ice to retard cell aggregation. The hemolymph was then filtered through $80 \mu \mathrm{m}$ mesh to eliminate cellular aggregates before analysis on a FACScalibur flow cytometer (Becton-Dickinson). The following parameters were measured following established methods (Delaporte et al. 2003): (1) Total hemocyte concentration (THC); (2) concentration of granulocytes; (3) concentration of hyalinocytes; and (4) \% viability/mortality by staining of live and dead hemocytes, respectively. Additionally, the following functional parameters were measured: (5) \% phagocytosis, as measured by the number of cells containing $\geq 3$ fluorescent latex beads ( $2 \mu \mathrm{m}$ diameter) after $2 \mathrm{~h}$ incubation at $18^{\circ} \mathrm{C}_{i}(6)$ phagocytosis capacity as measured by the mean number of beads per phagocytically active hemocyte; and (7) total oxidative activity, measured using the fluorescent probe $2^{\prime} 7^{\prime}$-dichlorofluorescein diacetate (DCFH-DA). The latter indicates the oxidative stress of the cells and/or their potential to kill non-self, engulfed particles by the production of reactive oxygen species. Hemocyte adhesion in the presence of Vibrio tapetis, a measure of the toxicity of the bacterium to host cells, was compared to controls in FSW (as per Choquet et al. 2003). In order to obtain sufficient numbers of hemocytes for the assay, it was necessary to pool hemolymph from 4 to 6 clams, which were separated according to treatment and whether they were burrowers or non-burrowers. Following hemolymph sampling, all clams were analyzed for SL, air-dried shell weight, and wet soft tissue weight. Clam soft tissues were then frozen at $-80^{\circ} \mathrm{C}$ for subsequent determination of individual condition index (CI) and toxin con- centration. Soft tissue DW was determined after lyophilization of frozen tissues for $48 \mathrm{~h}$. The individual $\mathrm{CI}$ of burrowers and non-burrowers was determined as $\mathrm{CI}=(\mathrm{DW}$ tissues/shell weight $)$ in $\mathrm{g} \times 100$. Shells of all clams were examined to assess their BRD status.

Toxin analysis. Toxin extracts of clam tissues and Alexandrium tamarense cells were obtained following previously described methods (MacQuarrie \& Bricelj 2008). Tissues of adult clams ( $\mathrm{n}=46$ from the toxic treatment, also used to determine the CI) were analysed individually. Pooled juveniles (4 to 6 samples of $\mathrm{n}=2$ to 10 clams from each of the FSW- and Vibrio tapetis-injected groups exposed to toxic algae) were sampled on Day 14 post-inoculation, at the end of the burrowing assay, and at the end of toxification on Day 16 post-inoculation. The frozen tissues were lyophilized and air-shipped for analysis to IMB/NRC, where they were weighed, pulverized, and extracted in $0.1 \mathrm{~mol} \mathrm{l}^{-1}$ acetic acid (HOAc) with a Polytron homogenizer, over an ice bath. Only 2 to 3 samples from the non- $A$. tamarense treated clams were similarly analyzed to confirm that they contained no detectable toxin levels. Alexandrium tamarense cells $\left(1 \times 10^{6}\right.$ cells) were extracted in $3 \mathrm{ml}$ of $0.03 \mathrm{~mol} \mathrm{l}^{-1}$ HOAc to maintain the integrity of individual toxins, using a Vibracell ultrasonicator. Toxin analysis by high-performance liquid chromatography with fluorescence detection (HPLC-FD) was performed following methods of Oshima (1995) with minor modifications. Individual toxins were quantified with certified external standards provided by IMB's certified reference materials program (CRMP). Concentrations of individual toxins were converted to STXeq using toxin-specific conversion factors (mouse units [MU] $\mathrm{mol}^{-1}$ ) and a conversion factor of $0.23 \mu \mathrm{g}$ STXeq $\mathrm{MU}^{-1}$ (Cembella et al. 1993). Individual toxicities were summed up to yield total toxicity in $\mu \mathrm{g}$ STXeq $100 \mathrm{~g}^{-1}$ tissue wet weight.

Statistical analysis. All percentages were arcsine transformed prior to analysis to normalize the data. In the juvenile clam experiment, it was obvious without statistical analysis, that certain treatments were different from others. In these cases (\% burrowing, \% mortality, and \% in each CDG), statistical analysis was reserved for differences that were not obvious. Percent burrowing and mortality were compared using a $t$-test for samples with equal variances, after confirming that there were no significant differences in variances. Survival trajectories were also compared using a stratified log-rank test for equality of survivor functions (STATA software). The distribution of CDGs was compared between treatments using a Pearson's $\chi$-squared test. The instantaneous growth coefficients in the 4 treatments were compared by 1-way ANOVA followed by Tukey's multiple comparisons. The CI of burrowed and non-burrowed adult clams in the toxic treatment 
was compared by ANOVA following verification that variances were homogeneous. To calculate the percent molar contribution of each toxin group to the total, the 2 epimers were added $(\mathrm{C} 1+\mathrm{C} 2$, and GTX2 + GTX3) since some epimerization may occur during extraction.
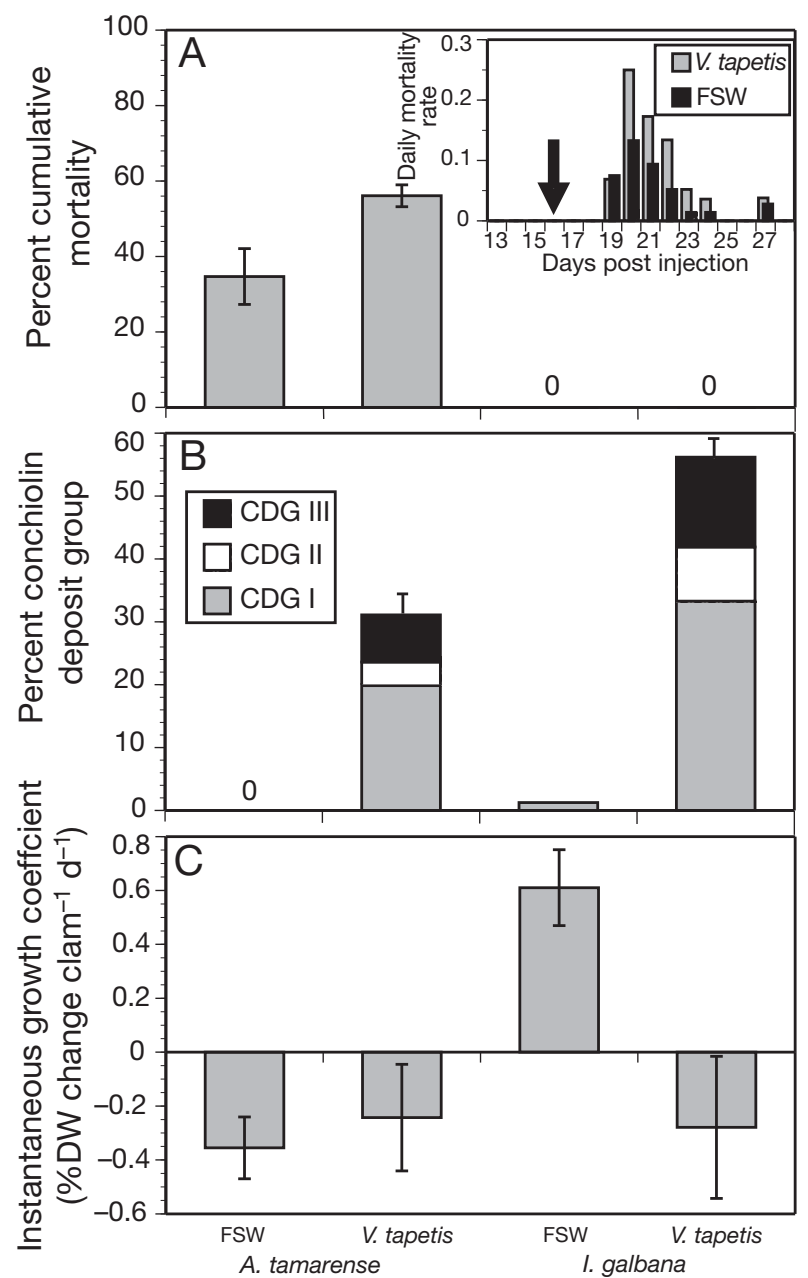

Fig. 2. Ruditapes philippinarum. A test of the combined effects of exposure to Vibrio tapetis and Alexandrium tamarense on juvenile Manila clams (Expt 1; see Fig. 1): (A) Mean percent cumulative mortality at the end of the experiment (inset shows the temporal progression of mortalities during Days 13 through 16 and after toxification; the arrow marks the end of toxification); (B) Mean percent prevalence of brown ring disease (BRD) stages; and (C) Instantaneous daily growth coefficient $(k)$ in terms of dry weight of soft tissues of juvenile Manila clams between Days 6 and 28 post-injection (see Fig. 1); initial mean DW = 19.71 mg ( $\pm 0.63 \mathrm{SE})$. Error bars in (A) and (C) represent the mean $( \pm \mathrm{SE})$ of 3 observations, 55 clams in each in A and 10 in C. BRD stages in (B) were scored from 1 to 7 according to Paillard \& Maes (1994) and grouped by severity as conchiolin deposit groups (CDG) I, II, and III (see 'Hemocyte response' in 'Materials and methods'). No BRD stage 7 clams were found in this study. The total BRD prevalence is the mean $( \pm \mathrm{SE})$ of 3 observations. In (B) for the A. tamarense diet, $\mathrm{n}=66$ for filtered seawater (FSW) and 53 for $V$. tapetis; for the Isochrysis galbana diet, $\mathrm{n}=80$ for filtered seawater (FSW) and 105 for $V$. tapetis
Hemocyte parameters were compared by ANOVA if their variances were homogeneous (Bartlett's test); otherwise, they were analysed using the KruskalWallis non-parametric test. For all tests, differences were considered significant at $\mathrm{p}<0.05$.

\section{RESULTS}

\section{Expt 1: juvenile Manila clams}

This experiment compared mortalities, BRD prevalence and growth (Fig. 2), and burrowing behavior (Fig. 3) between single and dual treatments of toxic algae and Vibrio tapetis.

\section{Mortality}

Cumulative mortalities occurring between the start of toxification and the end of the experiment $(28 \mathrm{~d}$ post-inoculation) were observed only in juvenile clams

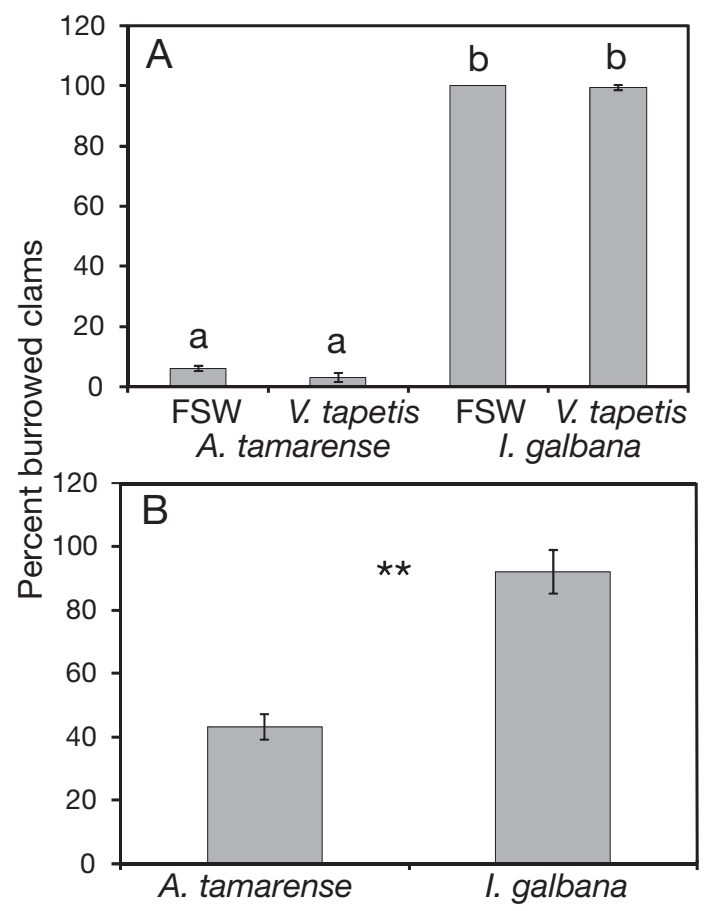

Fig. 3. Ruditapes philippinarum. (A) Percent of juvenile clams (12 mm SL; Expt 1) that burrowed within $2 \mathrm{~h}$ following $24 \mathrm{~h}$ exposure to either Isochrysis galbana (clone T-iso) or toxic Alexandrium tamarense (mean \pm SE of 3 observations, $\mathrm{n}=55$ clams each). Clams were injected with filtered seawater (FSW = controls) or Vibrio tapetis 2 wk before toxification began (see Fig. 1). Different letters indicate significantly different results ( $p \leq 0.05)$. (B) Percent of test population of adult Manila clams (36 mm SL) that burrowed within $5 \mathrm{~h}$ following $16 \mathrm{~h}$ exposure to either I. galbana (clone T-iso) or toxic A. tamarense (Expt 2) (mean \pm SE of 3 observations, 20 clams each except for $1 \mathrm{~A}$. tamarense tank with 16 clams). ${ }^{* *} 0.01<\mathrm{p} \leq 0.05$ 
fed Alexandrium tamarense (Fig. 2A), but differed significantly between FSW- and Vibrio tapetis-injected clams (34.7 and $56.1 \%$, respectively; $\mathrm{p}=0.03$ ). Nevertheless, daily mortalities for these 2 groups followed the same pattern. They were greatest $4 \mathrm{~d}$ following removal from the toxic diet and declined gradually thereafter (inset in Fig. 2A). Survivorship trajectories were also found to be significantly different between these 2 treatments (stratified log-rank test for equality of survivor functions; $\mathrm{p}<0.001$ ). In contrast, clams fed the Isochrysis galbana diet, whether injected with FSW or $V$. tapetis, showed $100 \%$ survival throughout the same period.

\section{Burrowing}

Severe and significant burrowing incapacitation (>93\% non burrowers) after $24 \mathrm{~h}$ toxification was observed only in treatments in which juveniles were fed toxic Alexandrium tamarense cells, whereas $100 \%$ of clams fed non-toxic algae (whether injected with FSW or Vibrio tapetis) reburrowed within $2 \mathrm{~h}$ (Fig. 3A). Thus, in vivo challenge with pathogenic $V$. tapetis did not affect burrowing behavior 2 wk post-inoculation.

\section{BRD prevalence}

The total prevalence of BRD (sum of CDG I, II, and III) in juvenile clams at Day 28 post-inoculation was highest $(56 \%)$ in clams challenged with Vibrio tapetis and fed the control algae, and was significantly different from $V$. tapetis-challenged clams $(32 \%)$ fed toxic algae $(\mathrm{p}=0.017)$ (Fig. 2B). Among control clams injected with FSW, only 1 (FSW and non-toxic algae), which had a stage-2 deposit, showed evidence of BRD. There was also a significant difference in the CDG distribution between the $2 \mathrm{~V}$. tapetis-injected treatments $(p=0.039)$. The incidence of clams with more advanced stages of CDG (CDGII and CDGIII) was higher in $V$. tapetis-challenged clams fed the control Isochrysis galbana diet, than in those fed toxic algae (Fig. 2B).

The clams injected with Vibrio tapetis and fed toxic algae had significantly lower BRD prevalence at the end of the experiment than those fed the nontoxic algae, but they also had much greater mortality (Fig. 2A,B). We considered the possibility that, during the experiment, BRD-affected clams in the toxic-algaefed group died in greater numbers than the controls, thereby disproportionately reducing prevalence in the final sample. Therefore, we compared the BRD prevalence and severity of clams that died during the experiment with that of live clams at the end of the experiment. A total of $21 \%$ of the $V$. tapetis-injected clams that died during the study had BRD symptoms, and of these, only $15 \%$ were in stages $>2$. This compares to $38 \%$ prevalence and $20 \%$ in stages $>2$, respectively, in the survivors. Even if the toxified clams had survived and the prevalence and severity of BRD had increased during the final week of the study, it is unlikely that it would have increased enough to account for the differential between the toxified and nontoxified clams at the final sampling.

\section{Growth}

The instantaneous daily growth of soft tissues $(k)$, calculated between Day 6 and Day 28 post-inoculation, was positive only in the control treatment (FSWinjected clams fed non-toxic algae), and significantly different from those of all other treatments $(p \leq 0.01)$ (Fig. 2C). The $k$ values of all other treatments were negative, indicative of tissue weight loss, and not significantly different from each other. Growth reflects only the $4 \mathrm{~d}$ period of continuous feeding, since before and after that clams were fed a maintenance diet insufficient to support growth.

\section{Expt 2: adult Manila clams}

This trial was designed to identify the potential individual variation in the susceptibility to PSTs of adult clams, as measured by their burrowing capacity, and to determine their hemocyte responses following shortterm exposure to a high-toxicity dinoflagellate strain.

\section{Burrowing}

Exposure for $16 \mathrm{~h}$ to a highly toxic Alexandrium tamarense strain resulted in a significant reduction in the percentage of adults that were capable of reburrowing relative to clams exposed to the non-toxic control diet of Isochrysis galbana ( $<<0.01$, Fig. 3B). There was, however, considerable variability among individuals of the same population in the susceptibility to PSTs, as measured by this behavioral index. In contrast to $100 \%$ burrowing of the non-toxified juveniles, only $87 \%$ of the adults in control tanks had burrowed after $2 \mathrm{~h}$ (vs. $38 \%$ on average in the toxic treatment). The burrowing response did not reach asymptotic values until $5 \mathrm{~h}$ of observation, when on average $42(\mathrm{SE}=5.4)$ and $92 \%(\mathrm{SE}=7.4)$ of the test population had burrowed in the toxic and non-toxic diets, respectively (Fig. 3A). The condition index (CI) of clams exposed to toxic algae, which averaged 4.15 $(\mathrm{SE}=0.25)$ and $3.71(\mathrm{SE}=0.85)$ in burrowers and non- 
burrowers, respectively, did not differ significantly between these 2 groups (ANOVA, $p=0.16$ ). This confirms that burrowing incapacitation was a response to PST exposure, and not attributable to low nutritional condition.

\section{Effects on hemocytes}

There were no significant differences in any of the hemocyte parameters measured between burrowers and non-burrowers fed either diet (Table 1). Therefore values were pooled for all clams within each diet for analysis of treatment effect. Compared to controls, short-term exposure to highly toxic Alexandrium tamarense cells resulted in a significant increase in total hemocyte concentration (THC), mainly due to an increase in granulocyte concentration, and a highly significant negative, although small effect on the hemocytes' phagocytic activity and capacity, but no effect on hemocyte viability or oxidative activity (Table 1). Pooled samples indicated that adhesion of clam hemocytes after in vitro exposure to Vibrio tapetis was not significantly affected by toxic algae and was statistically similar in burrowers and non-burrowers (ANOVA, $\mathrm{p}=0.32$ and $\mathrm{p}=0.98$, respectively).

The prevalence of BRD was $12.9 \%$ in clams from the toxified treatment and $16.7 \%$ in control tanks, and most were in CDGII. Therefore neither CI nor BRD status could explain the observed differences in hemocyte concentrations between the toxic treatment and controls.

\section{Toxin accumulation and biotransformation}

We here determined the toxicities attained by juveniles and adult clams following short-term exposure to a highly toxic diet, and the capacity for biotransformation of individual PSTs present in the diet. The toxicity of Alexandrium tamarense (strain PR18b) averaged 67.0 and $104.8 \mathrm{pg}$ STXeq cell ${ }^{-1}$ during the juvenile and adult experiments, respectively. Juvenile and adult clams accumulated PSTs at a comparable rate of 302 and $362 \mu \mathrm{g}$ STXeq $\mathrm{h}^{-1}$ respectively, although the former were exposed to one-half the $A$. tamarense concentration and a lower mean cell toxicity. Adult burrowers attained a higher mean toxicity than nonburrowers, $6018(\mathrm{SE}=383 ; \mathrm{n}=24)$, and $5528 \mu \mathrm{g}$ STXeq $100 \mathrm{~g}^{-1}(\mathrm{SE}=427 ; \mathrm{n}=21)$, respectively, but the difference was not statistically significant (ANOVA, p = 0.39 ) over this short period of toxin exposure.

The molar composition of individual toxins in the dinoflagellate cells was dominated by the more labile, but low-potency sulfocarbamoyl toxins C1+2 (66.2\%), followed by the high-potency carbamate toxins NEO $(21.0 \%)$, and STX $(8.4 \%)$, and a smaller contribution of GTX2+3 of intermediate potency (3.7\%) (Fig. 4). Although the epimers C1, C2, and GTX3, GTX2 were pooled for the statistical analysis below, C2 and GTX3 remained the dominant epimers in clam tissues during this relatively short period (16 to $24 \mathrm{~h}$ ) of toxification. Thus, the C2:C1 molar ratio averaged 3.74 and 4.59 in juveniles and adults, respectively, and the ratio GTX3:GTX2 averaged 4.33 and 4.43 in juveniles and adults, respectively.

Table 1. Results of flow cytometric analysis of hemocytes from adult Manila clams following 16 h exposure to toxic Alexandrium tamarense (treated, T) or Isochrysis galbana (control, C) - means (SE). Percent phagocytosis = percent hemocytes containing $\geq 3$ beads; phagocytosis capacity = number of beads per phagocytically active hemocyte; oxidative activity = fluorescence level of dichlorofluorescein diacetate (DCFH-DA) in arbitrary units. Significant differences are bold, and the direction of the effect is given in parentheses

\begin{tabular}{|c|c|c|c|}
\hline \multirow[t]{2}{*}{ Variable } & \multirow{2}{*}{$\begin{array}{l}\text { Treated }(\mathrm{SE})^{\mathrm{a}} \\
\text { Control }(\mathrm{SE})^{\mathrm{a}}\end{array}$} & \multicolumn{2}{|c|}{ Treated $(\mathrm{T})^{\mathrm{a}}$ vs. control $(\mathrm{C})$} \\
\hline & & Test & $\mathrm{p}$ \\
\hline Total hemocytes $\mathrm{ml}^{-1}$ (THC) & $\begin{array}{l}9.00 \times 10^{5}\left(1.13 \times 10^{5}\right) \\
6.07 \times 10^{5}\left(6.4 \times 10^{4}\right)\end{array}$ & Kruskal-Wallis & $0.018(\mathrm{~T}>\mathrm{C})$ \\
\hline Granulocytes $\mathrm{ml}^{-1}$ & $\begin{array}{l}2.78 \times 10^{5}\left(4.02 \times 10^{4}\right) \\
1.42 \times 10^{5}\left(2.07 \times 10^{4}\right)\end{array}$ & Kruskal-Wallis & $\mathbf{0 . 0 0 3 7}(\mathrm{T}>\mathrm{C})$ \\
\hline Hyalinocytes $\mathrm{ml}^{-1}$ & $\begin{array}{l}6.23 \times 10^{5}\left(7.82 \times 10^{4}\right) \\
4.65 \times 10^{5}\left(4.88 \times 10^{4}\right)\end{array}$ & Kruskal-Wallis & 0.052 \\
\hline Percent hemocyte mortality & $\begin{array}{l}3.04(0.44) \\
3.16(0.54)\end{array}$ & ANOVA & 0.90 \\
\hline Percent phagocytosis & $\begin{array}{l}36.53(1.84) \\
42.92(1.50)\end{array}$ & ANOVA & $0.011(\mathrm{~T}<\mathrm{C})$ \\
\hline Phagocytosis capacity & $\begin{array}{l}7.81(0.26) \\
8.79(0.25)\end{array}$ & ANOVA & $0.004(\mathrm{~T}<\mathrm{C})$ \\
\hline Oxidative activity & $\begin{array}{l}41.42(2.31) \\
41.83(2.42)\end{array}$ & ANOVA & 0.90 \\
\hline
\end{tabular}




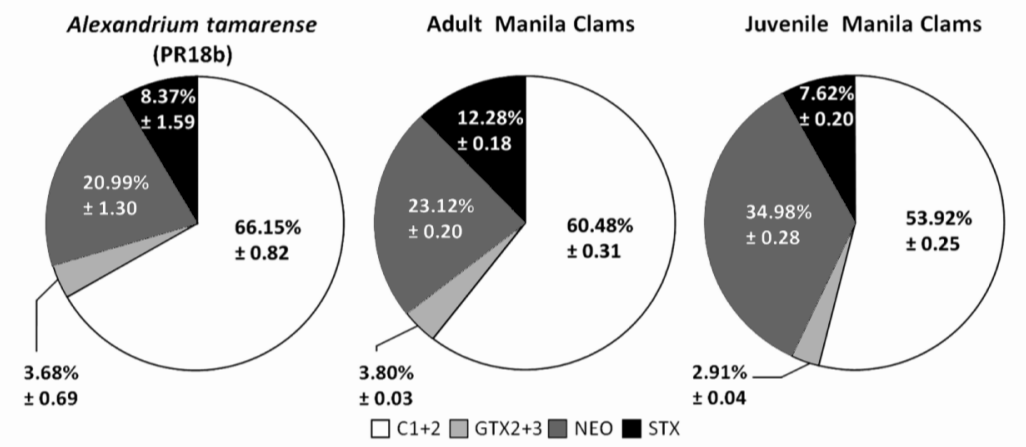

Fig. 4. Ruditapes philippinarum. Percent molar contribution (mean \pm SE) of paralytic shellfish toxins (PSTs) in Alexandrium tamarense (strain PR18b) cells $(\mathrm{n}=8)$, and adult and juvenile Manila clam tissues (46 clams and 10 samples of 2 to 10 pooled juveniles, respectively) after $\sim 1 \mathrm{~d}$ of exposure to A. tamarense (epimers are combined). C1+2 = sulfocarbamoyl toxins $\mathrm{C} 1+\mathrm{C} 2 ;$ GTX2+3 = gonyautoxins GTX2 + GTX3; NEO = neosaxitoxin; STX = saxitoxin. Toxins that made a negligible contribution to the total toxin in clam tissues $(<0.2 \%)$, namely dcGTX3 and GTX5 (= B1), are not shown although included in the totals; GTX1, GTX4, and dcGTX2 were not detected in clam tissues. Strain PR18b contained trace amounts of GTX4 and dcGTX3, but no detectable levels of GTX1, GTX2, GTX5, or dcGTX2. The ranking of potencies as determined by the mouse bioassay is: STX > NEO > GTXs > C toxins (see Fig. 3 in Bricelj \& Shumway 1998)

Over 16 h of toxification, adult Manila clams showed a significant decrease to $60.5 \%$ in the contribution of $\mathrm{C} 1+2(\mathrm{p}<0.001)$, a significant increase in that of NEO $(\mathrm{p}<0.01)$ and STX $(\mathrm{p}<0.001)$ to 23.1 and $12.3 \%$, respectively, and no significant change in GTXs ( $\mathrm{p}=$ 0.67) compared to the Alexandrium tamarense cells (Fig. 4). Values for all individuals were pooled for this analysis, since there was no difference in the total tissue toxin composition of burrowing and non-burrowing adult clams ( $p>0.23$ for all toxins). There was also no difference between the toxin composition of $A$. tamarense-exposed juveniles injected with Vibrio tapetis and FSW controls (the sample size of non-burrowers was too small to provide a reliable comparison with burrowers), so data were pooled for comparison with adults in Fig. 4. After $1 \mathrm{~d}$ of toxification, juveniles showed an even more pronounced decrease in the contribution of $\mathrm{C} 1+2$ (to $53.9 \%$ ) and increase in NEO (to $35.0 \%$ ) relative to $A$. tamarense cells (Fig. 4). The toxin composition of adults and juveniles differed significantly for all toxins ( $\mathrm{p}<0.001)$, with juveniles showing a greater reduction of $\mathrm{C} 1+2$ and greater increase in NEO than adults. Thus, the molar ratio of N-sulfocarbamoyl to carbamate toxins, which has been proposed as an index of the degree of toxin conversion (Cembella et al. 1993), was 2.25 in A. tamarense and was reduced to 1.71 in adults and 1.26 in juveniles. Only trace concentrations of dcGTX3 were detected in Manila clam tissues, and were also detected in trace amounts in A. tamarense (strain Pr18b), indicating that Manila clams are unable to perform rapid decarbamoylation of sulfocarbamoyl toxins to dcGTXs.

\section{DISCUSSION}

\section{Effects of PSTs on burrowing capacity of Ruditapes philippinarum}

This study is the first to determine the effects of laboratory exposure of Ruditapes philippinarum to a highly toxic PST-producing Alexandrium spp., as all prior studies used isolates of relatively low toxicity. Burrowing incapacitation within $\leq 1 \mathrm{~d}$ of toxin exposure was observed in both juveniles and adults, but the percentage of affected clams was greater among the former and incapacitation occurred sooner even though they were exposed to one-half the A. tamarense concentration and a $36 \%$ lower mean cell toxicity. Juveniles were exposed for 24 versus $16 \mathrm{~h}$ in adults (Fig. 3), but longer exposure of adults would not be expected to alter their burrowing results given that the percentage of clams burrowing became asymptotic within $5 \mathrm{~h}$ of toxin exposure. No adults died during $16 \mathrm{~h}$ of PST exposure. This agrees with prior findings that mortalities of subadult Mya arenaria (33 to $47 \mathrm{~mm}$ SL) typically started only after $\sim 1$ to $2 \mathrm{wk}$ of exposure to 100 cells ml $^{-1}$ of the same isolate (MacQuarrie \& Bricelj 2008). Greater vulnerability to PSTs of small clams was also demonstrated when burrowing and survival were compared between Mya arenaria $12 \mathrm{~mm}$ and $35 \mathrm{~mm}$ SL exposed to comparable toxin concentrations (Bricelj et al. 2010). Burrowing capacity is a critically important fitness parameter that is likely under strong natural selection, especially in juvenile bivalves before they attain a size refuge from predators.

In the field, the prevalence of BRD is greater in Manila clams collected at the surface than in those that remained burrowed (Paillard et al. 1994), suggesting that BRD may impair burrowing capacity or prevent maintenance of a normal position in sediment. In the present study, however, the ability to reburrow was not compromised in juvenile clams 2 wk following Vibrio inoculation, and no mortalities were induced by exposure to Vibrio alone. It is possible that negative effects on burrowing are associated only with more severely diseased clams.

A key finding of our study is that the burrowing assay allowed identification of toxin-resistant and sensitive adults within the same, Gulf of Morbihan, source population (45\% burrowers and $54 \%$ non-burrowers, respectively, following correction for $8 \%$ of clams that did not burrow in the controls). This area typically experiences relatively low maximum Alexandrium 
minutum concentrations $\left(<1 \mathrm{cell} \mathrm{m}^{-1}\right)$ compared to other sites along the northern French coast where maxima of up to 22800 and 5800 cells ml $^{-1}$ have been reported (Morlaix and the Abers Finistères, respectively; REPHY). The toxin concentration was comparable in adult burrowers and non-burrowers, indicating that the former were able to tolerate a high toxin body burden while retaining the ability to burrow. In Atlantic Mya arenaria populations, the prevalence of resistant individuals as measured by the burrowing response following laboratory exposure to toxic $A$. tamarense, was correlated with that measured by in vitro nerve resistance to STX (Bricelj et al. 2004). Earlier studies that ranked the nerve susceptibility of North American bivalve species to STX did not include Ruditapes philippinarum (Twarog et al. 1972, Kvitek \& Beitler 1991). However, if the individual variability in burrowing response shown in this study can be confirmed in future studies using the in vitro nerve assay, as was done in $M$. arenaria (Bricelj et al. 2005), $R$. philippinarum will provide a valuable, alternate model species in which to investigate the molecular/genetic basis for resistance to PSTs in bivalves.

\section{Toxin accumulation and biotransformation}

In this study adult, commercial-sized Ruditapes philippinarum attained relatively high toxicities, up to $\sim 6000 \mu \mathrm{g}$ STXeq $100 \mathrm{~g}^{-1}$, following only brief (16 h) exposure to a highly toxic Alexandrium tamarense isolate. This value exceeds the regulatory level for safe harvesting by $\sim 2$ orders of magnitude, and is comparable to the maximum $\left(6100 \mu \mathrm{g}\right.$ STXeq $\left.100 \mathrm{~g}^{-1}\right)$ reported for Manila clams in the field (British Columbia, Canada) (reviewed by Bricelj \& Shumway 1998). Thus, Manila clams could potentially affect public health in areas where they are exposed to high Alexandrium spp. concentrations and/or cell toxicities. Mya arenaria from a predominantly resistant population, as determined by the burrowing assay, exhibited an 8-fold higher PST uptake rate than clams from a mostly sensitive population over 2 wk of toxification (MacQuarrie \& Bricelj 2008). The fact that no difference was detected between adult burrowers and non-burrowers in our study is attributed to the short duration of toxin exposure.

Differences in the PST composition between bivalve tissues and the dinoflagellates they ingest are commonly observed due to metabolic/chemical transformation and/or differential retention/elimination, but the magnitude and rate of these changes varies greatly among species (Cembella et al. 1993, Bricelj \& Shumway 1998). A reduction in $C$ toxins and increase in $\mathrm{NEO}$ in clam tissues relative to Alexandrium tamarense were the 2 most salient changes documented in this study (Fig. 4). The greater changes observed in juvenile clams, evidenced by the greater reduction in $\mathrm{C}$ toxins, are consistent with their more rapid metabolism per unit body mass relative to adults. Conversion of the more labile $\mathrm{C}$ toxins, however, would be expected to result in an increase in GTXs and in STX, rather than in NEO, according to the pathways: $\mathrm{C} 1+2 \rightarrow \mathrm{GTX} 2+3 \rightarrow \mathrm{STX}$, due to enzymatic hydrolysis of N-sulfocarbamoyl toxins followed by reductive conversion of GTXs (Bricelj \& Shumway 1998). The anomalous changes observed (increase in NEO) could result from differential retention of individual toxins, e.g. more rapid elimination of GTXs and/or selective retention of NEO. It is difficult to compare our toxin composition results with prior studies in Manila clams (Lassus et al. 1989, 1994, Samsur et al. 2006) in which tissues were extracted in strong acid $(0.1 \mathrm{HCl})$ using the AOAC method, which is known to affect the integrity of individual PSTs. Overall, our results indicate that Ruditapes philippinarum resembles Mya arenaria in its relatively limited capacity for toxin conversion, demonstrated both in vivo (Bricelj \& Shumway 1998) and in vitro (Fast et al. 2006).

Manila clams were not capable of rapid (24 h) decarbamoylation of PSTs. In contrast, decarbamoyl (dc) toxins are produced preferentially and very rapidly (within a few h of feeding on toxic cells) from N-sulfocarbamoyl toxins, as well as secondarily and at a slower rate from their corresponding carbamate toxins in some bivalves such as surf clams Spisula solidissima (Cembella et al. 1993, Bricelj \& Shumway 1998). Rapid decarbamoylation of $\mathrm{C}$ toxins to dcGTXs (up to $90 \%$ conversion within $4 \mathrm{~h}$ in the digestive gland), and slower decarbamoylation of GTXs to dcGTXs, was demonstrated in vitro in littleneck clams Protothaca staminea, in which the reaction appears to be enzymatically mediated (Sullivan et al. 1983, Fast et al. 2006).

\section{Effects of PSTs on Manila clam hemocytes}

No adverse, direct effects on hemocytes were previously found by in vitro exposure of Ruditapes philippinarum hemolymph to extracts of Alexandrium tamarense (strain PR18b) containing high concentrations of PSTs, although a non-PST producing Alexandrium strain elicited strong adverse effects (Ford et al. 2008). Similarly, no effects of in vivo exposure to toxic Alexandrium spp. on hemocytes were found in oysters Crassostrea virginica and C. gigas, although they attained only low toxicities (<130 $\mu$ g STXeq $100 \mathrm{~g}^{-1}$ ) (Hégaret et al. 2007b). In the present study, in which $R$. philippinarum attained much higher toxicities, a significant, deleterious effect of $A$. tamarense on hemocyte function was found only for percent phagocytosis (15\% reduction, 
$\mathrm{p} \leq 0.05)$ and phagocytic capacity $(11 \%$ reduction, $\mathrm{p} \leq$ 0.01). Furthermore, exposure to A. tamarense led to a significant, 1.5-fold increase in total hemocyte concentrations (THC) ( $\mathrm{p}$ 0.05), and a doubling of granulocytes. The latter are the most powerfully phagocytic cells in Ruditapes spp. and thus considered most effective in cellular defense (López et al 1997, Donaghy et al. 2009). Toxified clams showed a $26 \%$ increase in the total number of phagocytic hemocytes $($ THC $\times$ percent phagocytosis) relative to control clams.

In contrast to our results, Galimany et al. (2008a) documented a significant reduction in the number of circulating eosinophilic hemocytes of Mytilus edulis, exposed for $9 \mathrm{~d}$ to a low-toxicity Alexandrium fundyense isolate $\left(0.43 \mathrm{pg}\right.$ STXeq cell $\left.{ }^{-1}\right)$ relative to controls fed non-toxic Rhodomonas spp. Histology indicated that this depletion was associated with hemocyte migration into the alimentary canal via diapadesis. Given the results of Ford et al. (2008), however, it cannot be ruled out that these observations are related to a non-PST toxic metabolite. Exposure of mussels to the toxic dinoflagellate Prorocentrum minimum also showed migration of hemocytes to the alimentary canal, yet there were no detectable effects on hemocyte concentration or functions (Galimany et al. 2008b). Exposure of Ruditapes philippinarum to P. minimum for $6 \mathrm{~d}$ led to a significant $(17 \%)$ reduction in phagocytosis, but no effects on hemocyte mortality and concentration, reactive oxygen species (ROS) production, or agglutination activity, yet it was associated with histological abnormalities (myopathy) in the foot and adductor muscle (Hégaret et al. 2009).

The increase in hemocyte concentrations detected in our study following short-term (16 h), acute exposure of adult Manila clams to a highly-toxic dinoflagellate cannot be clearly associated with an increased immune response (Adamo 2004), as it could reflect differences in algal diets (Delaporte et al. 2003) or redistribution of hemocytes between tissues and the circulatory system resulting from PST-induced paralysis. Our interpretation of in vitro trials using the same toxic isolate (Ford et al 2008) and the hemocytic analysis from this study is that short-term $(\sim 1 \mathrm{~d})$ exposure to highly toxic Alexandrium tamarense (strain Pr18b) does not compromise hemocyte numbers or function, as measured by most of the parameters tested, although it was sufficient to induce foot paralysis and, thus, burrowing incapacitation. This suggests that behavioral responses are more sensitive, and may respond more rapidly, than hemocyte functional responses to the detrimental effects of PSTs. For example, highly reproducible behavioral effects of exposure to A. minutum were documented in Crassostrea gigas, as measured by valve activity, including a significant increase in the number of valve microclosures within
$1 \mathrm{~d}$ of exposure to the toxic diet (Tran et al. 2010). In

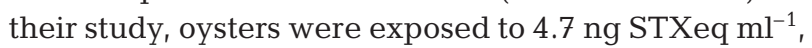
a value comparable to that (3.4 ng STXeq $\mathrm{ml}^{-1}$ ) maintained in our juvenile experiment.

\section{Single vs. interactive effects of Alexandrium tamarense and Vibrio tapetis in juvenile Manila clams}

Juvenile clams from the high-toxicity Alexandrium tamarense treatment experienced tissue weight loss and high mortalities, unlike those fed the control diet (Fig. 2A,C). Juvenile Manila clams showed a significant reduction in soft-tissue growth when fed a unialgal diet of a weakly toxic A. tamarense strain (ATCI01, $3.2 \mathrm{pg}$ STXeq cell ${ }^{-1}$ ) for $15 \mathrm{~d}$ relative to controls fed Thalassiosira pseudonana, although they suffered no mortalities (Li et al. 2002). In their study, scope for growth (SFG) of adult Manila clams, calculated from physiological rates, was also sharply reduced when this toxic strain was offered in increasing proportions in a mixed diet relative to a diatom control. In the unialgal toxic diet, both absorption efficiency and clearance rate $(\mathrm{CR})$ were significantly reduced, and SFG became negative. Thus, negative growth of $A$. tamarense-exposed juvenile clams in our study is likely, at least partly due to inhibition of clam feeding and absorption, although the high mortalities and the burrowing incapacitation observed also point to toxininduced effects unrelated to nutritional deficiency. MacQuarrie \& Bricelj (2008) suggested that high mortalities of Mya arenaria juveniles exposed to the same PR18b strain used in our study might be caused by hypoxia of the pallial cavity resulting from toxininduced paralysis and lack of irrigation. Whatever the underlying mechanism, Manila clams are clearly much more sensitive to the effects of PSTs than mussels, and more comparable to softshell clams. Thus, a unialgal diet of $A$. tamarense (toxicity $=9.5 \mathrm{pg}$ STXeq cell ${ }^{-1}$ ) supported positive growth of Mytilus edulis juveniles, although $26 \%$ lower than those on a diatom diet, but no mortalities (Bricelj et al. 1993), and yielded comparable growth to diatom controls in Perna viridis juveniles fed strain ATCI01 (Li et al. 2002).

In the present study, Vibrio tapetis-injected juveniles fed the control diet for $4 \mathrm{~d}$ followed by $12 \mathrm{~d}$ on a maintenance diet also exhibited weight loss, whereas those in the control treatment showed positive growth. Plana \& Le Pennec (1991) found that $V$. tapetis-injected juvenile Manila clams showed adverse changes in the morphology of the digestive tubules relative to FSW controls in both fed and starved treatments $30 \mathrm{~d}$ postinoculation. The reduction in percent of absorptive stages $1+2$ (from 92 to $52 \%$ in fed clams) and increase 
in degenerative stages 3+4 (from 8 to $47 \%$ ), were comparable in clams with both early and advanced stages of BRD, and were similar to those associated with starvation. Juveniles injected with $V$. tapetis also exhibited a significantly lower tissue DW compared to controls after $30 \mathrm{~d}$ of starvation, which was attributed to loss of glycogen reserves (Plana et al. 1996). Feeding resumption from Day 30 to 50, however, led to an increase in glycogen only in control clams injected with FSW. Glycogen content by the end of the feeding period was inversely related to the severity of BRD symptoms of $V$. tapetis-injected clams, indicating that BRD caused irreversible changes in the digestive gland's ability to store carbohydrate reserves, although clams recovered from visible signs of BRD. We thus suggest that tissue weight loss of infected juveniles in the present study, despite ad libitum food availability over $4 \mathrm{~d}$, was likely a direct effect of $V$. tapetis-induced atrophy of the digestive gland and thus impaired absorption, although CR may also have been compromised. Prior studies confirm that naturally BRD-affected adult Ruditapes philippinarum experienced a decrease in CI and glycogen (Goulletquer et al. 1989, Paillard 1992). Furthermore, the CI, CR, and feeding time of field-infected adults were reduced relative to asymptomatic clams, although this effect was significant only for individuals with advanced stages of BRD (CDG $\geq 4$ to 5) (FlyeSainte Marie et al. 2007). BRD severity was also negatively correlated with respiration rate, but examination of these authors' data suggests that the rate of this decline with increasing CDG was less pronounced than that of $\mathrm{CR}$.

Our results both supported and rejected our hypothesis that combined exposure to Vibrio tapetis and toxic algae would aggravate the effects of either of these alone on the progression of BRD. The clams subjected to the dual challenge experienced much higher mortality than those fed the nontoxic diet, which had no deaths, and somewhat higher mortality than those exposed to the toxic diet but injected with FSW (Fig. 2A). Yet, this dual exposure to both Alexandrium tamarense and $V$. tapetis was associated with lower BRD prevalence by the end of the experiment than the Isochrysis galbana $+V$. tapetis treatment. This result could not be explained by higher mortality of symptomatic clams in the dual treatment, suggesting that the toxic algal exposure may have slowed the progression of BRD (Fig. 2B). Several mechanisms can be invoked to explain this outcome. First, A. tamarense may be directly toxic to $V$. tapetis. Second, the overall negative effect of toxic algal exposure on metabolism, as indicated by the loss of tissue weight, could have inhibited the clams' capacity to produce the conchiolin deposit. This may have been exacerbated if hypoxia occurred in the pallial cavity, as suggested for $M$. arenaria (Mac-
Quarrie \& Bricelj 2008). A related finding was reported for juvenile Crassostrea virginica injected with the bacterial agent of Roseobacter oyster disease (ROD, also known as juvenile oyster disease, JOD). Juveniles $<10 \mathrm{~mm}$ often died before they were able to form the characteristic conchiolin ring on the inner shell, whereas larger juveniles did produce the characteristic conchiolin response (Maloy et al. 2007). For both BRD and ROD, the bacterial agents are often found trapped between layers of the conchiolin deposit and under shell layers following repair, suggesting that it may be a defense mechanism (Paillard et al. 1994). Thus, the failure of juvenile Manila clams to produce conchiolin may be a measure of the failure of a defense system that led to high mortality.

The possibility that exposure to PSTs resulted in selective or earlier mortality of clams with BRD signs was excluded by determining the CDG stage of dead clams throughout the course of the experiment (see 'BRD prevalence' in 'Results'). It remains possible, however, that exposure to Alexandrium tamarense stimulated the clams' cellular response against Vibrio tapetis. Allam et al. (2001) found a positive correlation between the concentration of phagocytically active cells in both hemolymph and extrapallial fluid with resistance to BRD in experimentally injected Ruditapes spp. We can only speculate on a potential role of hemocytes in suppressing BRD prevalence in juveniles exposed to $A$. tamarense, since the $26 \%$ increase in the number of phagocytic hemocytes was determined in adults, and following only short-term exposure to $A$. tamarense.

There are parallels between the results of our study and a prior study in which exposure of Ruditapes philippinarum to Karenia selliformis, a dinoflagellate with strong hemolytic action and producer of gymnodimine, reduced the prevalence of Perkinsus olseni in infected clams (da Silva et al. 2008). Exposure to K. selliformis had no effect on the clams' hemocyte concentration, percent mortality, percent phagocytosis, or ROS production, although it caused a significant decrease in mean hemocyte size and percent apoptotic cells. Intact $K$. sellifomis cells, however, induced increased mortality of $P$. olseni in vitro, indicating that direct toxicity to the parasite, rather than a change in the host's hemocyte concentrations or function, was responsible for the transient abatement of parasite prevalence and intensity of infection. Similarly, in vitro exposure to both $P$. minimum culture medium and whole cells resulted in a significant increase in the mortality of $P$. olseni trophozoites (Hégaret et al. 2009). Therefore, additional work is needed on the dose-dependent effects of toxic algae on bivalve pathogens, so far examined for very few toxic species, to better understand their combined role in the natural environment. 
Acknowledgements.We thank Scott MacQuarrie, IMB/NRC, for his technical assistance, including shipping of equipment and materials to France, Melissa Anderson for extraction of clam tissues for PST analysis, and Kelley Reeves for PST analysis. We also thank personnel at LEMAR including Philippe Soudant, technician Nelly Le Goïc, graduate students Nolwenn Trinkler, Hansy Haberkorn, and especially Marie-Agnès Travers for participation in the injection of juvenile clams and hemolymph extraction of adult clams; Alain Le Mercier for problem-solving; Jacques Le Fèvre and $P$. Soudant for loan of equipment; Alain Marhic for culture of non-toxic algae; and personnel at the Argenton IFREMER hatchery, René Robert and Stéphane Pouvreau, for holding and feeding adult clams prior to their transfer to LEMAR for experiments. We also thank Jean François Auvray from the SATMAR hatchery for providing the juvenile clams. This paper is a result of research funded by the National Oceanic and Atmospheric Administration Center for Sponsored Coastal Ocean Research under NOAA-ECOHAB award \#NA06NOS4780256 to the University of Washington, and is ECOHAB publication \#617. Funding was also provided via a Centre National de Recherche Scientifique (CNRS) visiting researcher position to V.M.B. during her sabbatical at LEMAR/IUEM.

\section{LITERATURE CITED}

Adamo SA (2004) How should behavioural ecologists interpret measurements of immunity? Anim Behav 68: 1443-1449

Allam B, Ford SE (2006) Effects of the pathogenic Vibrio tapetis on defence factors of susceptible and non-susceptible bivalve species. I. Hemocyte changes following in vitro challenge. Fish Shellfish Immunol 20:374-383

Allam B, Ashton-Alcox KA, Ford SE (2001) Hemocyte parameters associated with resistance to brown ring disease in Ruditapes spp. clams. Dev Comp Immunol 25:365-375

Bougrier S, Lassus P, Beliaeff B, Bardouil M and others (2001) Feeding behavior of individuals and groups of king scallops (Pecten maximus) contaminated experimentally with PSP toxins and detoxifed. In: Hallegraef G, Blackburn SI, Bolch CJ, Lewis RJ (eds) Harmful algal blooms. IOC of UNESCO, Paris, p 407-410

Bricelj VM, Shumway SE (1998) Paralytic shellfish toxins in bivalve molluscs: occurrence, transfer kinetics, and biotransformation. Rev Fish Sci 6:315-383

Bricelj VM, Greene M, Cembella AD (1993) Growth of mussels, Mytilus edulis, on toxic Alexandrium fundyense and fate of dinoflagellate cells following gut passage. In: Smayda TJ, Shimizu Y (eds) Phytoplankton blooms in the sea. Elsevier, New York, NY, p 371-376

Bricelj VM, MacQuarrie SP, Twarog B, Trainer VL (2004) Characterization of sensitivity to PSP toxins in North American populations of the softshell clam Mya arenaria. In: Steidinger KA, Landsberg KH, Tomas CR, Vargo GA (eds) Harmful algae, 2002. Florida Fish and Wildlife Conservation Commission, Florida Institute of Oceanography and IOC of UNESCO, St. Petersburg, p 172-174

Bricelj VM, Connell LB, Konoki K, MacQuarrie SP, Scheuer T, Catterall WA, Trainer VL (2005) Sodium channel mutation responsible for saxitoxin resistance in clams increases risk of PSP. Nature 434:763-767

Bricelj VM, MacQuarrie SP, Doane JAE, Connell LB (2010) Evidence for selection for resistance to paralytic shellfish toxins during early life history in softshell clam, Mya arenaria, populations. Limnol Oceanogr 55:2463-2475
Catterall WA (2000) From ionic currents to molecular mechanisms: the structure and function of voltage-gated sodium channels. Neuron 26:13-25

Cembella AD, Shumway SE, Lewis NI (1993) Anatomical distribution and spatio-temporal variation in paralytic shellfish toxin composition in two bivalve species from the Gulf of Maine. J Shellfish Res 12:389-403

Cheng TC (1996) Hemocytes: forms and functions. In: Kennedy VS, Newell RIE, Eble F (eds) The eastern oyster Crassostrea virginica. Maryland Sea Grant College, p 299-333

Choquet G, Soudant P, Lambert C, Nicolas JL, Paillard C (2003) Reduction of adhesion properties of Ruditapes philippinarum hemocytes exposed to Vibrio tapetis. Dis Aquat Org 57:109-116

Connell L, MacQuarrie SP, Twarog B, Iszard M, Bricelj VM (2007) Population differences in nerve resistance to paralytic shellfish toxins in the softshell clam, Mya arenaria, associated with sodium channel mutations. Mar Biol 150: 1227-1236

> Dang C, de Montaudouin X, González P, Mesmer-Dudons N, Caill-Milly N (2008) Brown muscle disease (BMD), an emergent pathology affecting Manila clam Ruditapes philippinarum in Arcachon Bay (SW France). Dis Aquat Org 80:219-228

da Silva PM, Hégaret H, Lambert C, Wikfors GH, Le Goïc N, Shumway SE, Soudant P (2008) Immunological responses of the Manila clam (Ruditapes philippinarum) with varying parasite (Perkinsus olseni) burden, during a longterm exposure to the harmful alga, Karenia selliformis, and possible interactions. Toxicon 51:563-573

Delaporte M, Soudant P, Moal J, Lambert C and others (2003) Effect of a mono-specific algal diet on immune functions in two biovalve species - Crassostrea gigas and Ruditapes philippinarum. J Exp Biol 206:3053-3064

> Donaghy L, Lambert C, Choi KS, Soudant P (2009) Hemocytes of the carpet shell clam (Ruditapes decussatus) and the Manila clam (Ruditapes philippinarum): current knowledge and future prospects. Aquaculture 297:10-24

Fast MD, Cembella AD, Ross NW (2006) In vitro transformation of paralytic shellfish toxins in the clams Mya arenaria and Protothaca staminea. Harmful Algae 5:79-90

Flassch JP, Leborgne Y (1992) Introduction in Europe, from 1972 to 1980, of the Japanese manila clam (Tapes philippinarum) and effects on aquaculture production and natural settlement. ICES Mar Sci Symp 194:92-96

- Flye-Sainte Marie J, Pouvreau S, Paillard C, Jean F (2007) Impact of brown ring disease on the energy budget of the Manila clam Ruditapes philippinarum. J Exp Mar Biol Ecol 349:378-389

Ford SE, Bricelj VM, Lambert C, Paillard C (2008) Deleterious effects of a non-PST bioactive compound(s) from Alexandrium tamarense on bivalve hemocytes. Mar Biol 154: $241-253$

Galimany E, Sunila I, Hégaret H, Ramón M, Wikfors GH (2008a) Experimental exposure of the blue mussel (Mytilus edulis, L.) to the toxic dinoflagellate Alexandrium fundyense: histopathology, immune responses, and recovery. Harmful Algae 7:702-711

Galimany E, Sunila I, Hégaret H, Ramón M, Wikfors GH (2008b) Pathology and immune response of the blue mussel (Mytilus edulis L.) after an exposure to the harmful dinoflagellate Prorocentrum minimum. Harmful Algae 7: 630-638

Goedken M, Morsey B, Sunila I, De Guise S (2005) Immunomodulation of Crassostrea gigas and Crassostrea virginica cellular defense mechanisms by Perkinsus marinus. J Shellfish Res 24:487-496 
Goulletquer P (1997) A bibliography of the Manila clam Tapes philippinarum. IFREMER, R IDRV-97.021RN/La Tremblade

Goulletquer P, Héral M, Béchemin C, Richard P (1989) Caractérisation des anomalies de calcification chez la palourde japonaise Ruditapes philippinarum: comparaison des compositions en acides aminés de différentes parties de la coquille analyses par HPLC. Aquaculture 81:169-183

Guillard RRL, Hargraves PE (1993) Stichochrysis immobilis is a diatom, not a chrysophyte. Phycologia 32:234-236

Guillard RRL, Ryther JH (1962) Studies of marine planktonic diatoms. I. Cyclotella nana Hustedt and Detonula confervacea Cleve. Can J Microbiol 8:229-239

> Hégaret H, Wikfors GH (2005) Effects of natural and fieldsimulated blooms of the dinoflagellates Prorocentrum minimum upon hemocytes of eastern oysters, Crassostrea virginica, from two different populations. Harmful Algae 4:201-209

- Hégaret H, da Silva PM, Wikfors GH, Lambert C, De Bettignies T, Shumway SE, Soudant S (2007a) Hemocyte responses of Manila clams, Ruditappes philippinarum, with varying parasite, Perkinsus olsenii, severity to toxicalgal exposures. Aquat Toxicol 84:469-479

Hégaret H, Wikfors GH, Soudan P, Lambert C, Shumway SE, Bérard JP, Lassus P (2007b) Toxic dinoflagellates (Alexandrium fundyense and A. catenella) have minimal apparent effects on oyster hemocytes. Mar Biol 152:441-447

> Hégaret H, da Silva PM, Sunila I, Shumway SE and others (2009) Perkinsosis in the Manila clam Ruditapes philippinarum affects responses to the harmful-alga, Prorocentrum minimum. J Exp Mar Biol Ecol 371:112-120

> Keller MD, Bellows WK, Guillard RRL (1988) Microwave treatment for sterilization of phytoplankton culture media. J Exp Mar Biol Ecol 117:279-283

Kvitek RG, Beitler MK (1991) Relative insensitivity of butter clam neurons to saxitoxin: a pre-adaptation for sequestering paralytic shellfish poisoning toxins as a chemical defense. Mar Ecol Prog Ser 69:47-54

> Lassus P, Frémy JM, Ledoux M, Bardouil M, Bohec M (1989) Patterns of experimental contamination by Protogonyaulax tamarensis in some French commercial shellfish. Toxicon 27:1313-1321

Lassus P, Ledoux M, Bardouil M, Bohec M, Erard E (1994) Kinetics of Alexandrium minutum Halim toxin accumulation in mussels and clams. Nat Toxins 2:329-333

Li SC, Wang WX (2001) Radiotracer studies on the feeding of two marine bivalves on the toxic and nontoxic dinoflagellate Alexandrium tamarense. J Exp Mar Biol Ecol 263: 65-75

Li SC, Wang WX, Hsieh DPH (2002) Effects of toxic dinoflagellate Alexandrium tamarense on the energy budgets and growth of two marine bivalves. Mar Environ Res 53:145-160

> Lilly EL, Kulis DM, Gentien P, Anderson DM (2002) Paralytic shellfish poisoning toxins in France linked to a humanintroduced strain of Alexandrium catenella from the western Pacific: evidence from DNA and toxin analysis. J Plankton Res 24:443-452

> López C, Carballal MJ, Azevedo C, Villalba A (1997) Differential phagocytic ability of the circulating haemocyte types of the carpet shell clam Ruditapes decussatus (Mollusca: Bivalvia). Dis Aquat Org 30:209-215

MacQuarrie SP, Bricelj VM (2008) Behavioral and physiologi-

Editorial responsibility: Hans Heinrich Janssen, Oldendorf/Luhe, Germany cal responses to PSP toxins in Mya arenaria populations in relation to previous exposure to red tides. Mar Ecol Prog Ser 366:59-74

> Maloy AP, Barber BJ, Boettcher KJ (2007) Use of the 16S-23S rDNA internal transcribed spacer of Roseovarius crassostrae for epizootiological studies of juvenile oyster disease (JOD). Dis Aquat Org 76:151-161

Oshima Y (1995) Post-column derivatization HPLC methods for paralytic shellfish poisons. In: Hallegraeff GM, Anderson DM, Cembella AD (eds) Manual on harmful marine microalgae. IOC Manuals and Guides No. 33, UNESCO, Paria, p 81-94

> Oubella R, Maes P, Paillard C, Auffret M (1993) Experimentally induced variation in hemocyte density for Ruditapes philippinarum and $R$. decussatus (mollusc, Bivalvia). Dis Aquat Org 15:193-197

Paillard C (1992) Etiologie et caractérisation de la maladie de l'anneau brun chez la palourde d'élevage, Ruditapes philippinarum. $\mathrm{PhD}$ thesis, University of Western Brittany, Brest

Paillard C, Maes P (1990) Étiologie de la maladie de l'anneau brun chez Tapes philippinarum: pathogénicité d'un Vibrio sp., C.R. Acad Sci Paris 310:15-20

- Paillard C, Maes P (1994) Brown ring disease in the Manila clam Ruditapes philippinarum: establishment of a classification system. Dis Aquat Org 19:137-146

Paillard C, Maes P, Oubella R (1994) Brown ring disease in clams. Annu Rev Fish Dis 4:219-240

Paillard C, Allam B, Oubella R (2004) Effect of temperature on defense parameters in Manila clam Ruditapes philippinarum challenged with Vibrio tapetis. Dis Aquat Org 59: $249-262$

Paillard C, Korsnes K, Le Chevalier P, Le Boulay C and others (2008) Vibrio tapetis-like strain isolated from introduced Manila clams Ruditapes philippinarum showing symptoms of brown ring disease in Norway. Dis Aquat Org 81: 153-161

- Plana S, Le Pennec M (1991) Alterations in the digestive diverticula and nutritional consequences in the clam Ruditappes philippinarum infected by Vibrio. Aquat Living Resour 4:255-264

> Plana S, Sinquin G, Maes P, Paillard C, Le Pennec M (1996) Variations in biochemical composition of juvenile Ruditapes philippinarum infected by Vibrio sp. Dis Aquat Org 24:205-213

- Samsur M, Yamaguchi Y, Sagara T, Takatani T, Arakawa O, Noguchi T (2006) Accumulation and depuration profiles of PSP toxins in the short-necked clam Tapes japonica fed with the toxic dinoflagellate Alexandrium catenella. Toxicon 48:323-330

Sullivan JJ, Iwaoka WT, Liston WT (1983) Enzymatic transformation of PSP toxins in the littleneck clam Protothaca staminea. Biochem Biophys Res Commun 114:465-472

Tran D, Haberkorn H, Soudant P, Ciret P, Massabuau JC (2010) Behavioral responses of Crassostrea gigas exposed to the harmful algae Alexandrium minutum. Aquaculture 298:338-345

> Twarog BM, Hidaka T, Yamaguchi H (1972) Resistance to tetrodotoxin and saxitoxin in nerves of bivalves molluscs. Toxicon 10:273-278

Vila M, Garcés E, Masó M, Camp J (2001) Is the distribution of the toxic dinoflagellate Alexandrium catenella expanding along the NW Mediterranean coast? Mar Ecol Prog Ser 222:73-83

Submitted: December 2, 2010; Accepted: February 28, 2011 Proofs received from author(s): May 11, 2011 